\title{
Response of young rats to rehabilitation with diets containing different amounts of protein after deprivation of protein or of calories
}

\author{
By VERA CABAK, J. W. T. DICKERSON AND MARGARET W. STANIER \\ Medical Researci Council Department of Experimental Medicine, \\ University of Cambridge
}

(Received I April I963-Revised 27 May 1963)

Young rats fed on a diet deficient in protein or in calories failed to grow and lost nitrogen from their bodies (Čabak, Dickerson \& Widdowson, 1963). The rehabilitation of some of these animals provided an opportunity to study three separate problems.

(I) In parts of the world where protein deficiency is common it is uncertain whether there is any advantage in rehabilitating malnourished children on diets very high in protein. Some of the rats were rehabilitated on unlimited amounts of the high-protein diet used by Cabak et al., and their progress was compared with that of others on the same diet mixed with starch.

(2) Some of the organs of the rats investigated during deprivation had lost a greater proportion of their initial $\mathrm{N}$ than others. The distribution of the $\mathrm{N}$ retained during rehabilitation was studied to find out whether the organs that lost the most regained the most.

(3) In man the amount of $\mathrm{N}$ retained has often been found to bear no exact relationship to the simultaneous increase in body-weight. It has been so in children growing normally (Benjamin, I9I4; Bray, I953; Fomon, I96I), in children and adults recovering from undernutrition (Widdowson \& McCance, 1954; Holmes, Jones \& Stanier, 1954), and in normal adults increasing in weight during overfeeding (Passmore, Meiklejohn, Dewar \& Thow, 1955). In all these instances, the gain in body-weight was less than had been predicted from the $\mathrm{N}$ retention, on the assumption that $\mathrm{N}$ forms 3.25 $3.4 \%$ of the lean body mass, or $5.3 \%$ of the cell mass. Waterlow \& Wills (1960) and Waterlow (196I), however, who assumed that $\mathrm{N}$ forms $2.4 \%$ of the normal infant's body, found that the gains of weight of I-year-old infants in Jamaica in the final stage of recovery from kwashiorkor corresponded to their $\mathrm{N}$ retention. The lack of relationship between increase in body-weight and $\mathrm{N}$ retention has occurred often enough to have provoked comment, and the origins of the inconsistency have been sought (Wallace, 1959; Waterlow, Cravioto \& Stephen, 1960). In the work now described, the opportunity was taken to measure the intake and excretion of $\mathrm{N}$ of some of the rats and to compare the amount retained with the increase in the amounts found in the bodies of the rats over the same period. 
EXPERIMENTAL

\section{Design of the experiment}

All the rats remaining alive at the end of the experiment described in the previous paper (Cabak et al. 1963) were included in this study. Twelve rats that had had the low-protein diet, six that had had the high-protein diet in restricted amounts and twelve well-nourished control animals were available. All the animals were $6 \mathrm{r}$ days old when the period of rehabilitation began, and the rehabilitation was continued for 27 days. Half the animals in each group were given unlimited amounts of the highprotein diet used in restricted amounts during the period of deprivation, and the remainder were given unlimited amounts of a mixture of the high-protein diet and soluble starch (Hopkin \& Williams Ltd) in the proportion $\mathrm{I}: 2$. The air-dry high-protein diet contained $48 \mathrm{~g}$ protein/100 $\mathrm{g}$, and the protein and starch diet contained $13.5 \mathrm{~g}$ protein/roog.

Minerals and vitamin B complex powder were added to all the diets as described in the previous paper except that for the animals being fed on the high-protein diet and starch the quantity of vitamin B complex powder was doubled. All the animals had a continuous and unlimited supply of drinking water throughout.

\section{Balance technique}

Six of the rats undergoing rehabilitation on the high-protein and starch mixture were placed in metabolism cages for the whole period of rehabilitation, and their intake and output of $\mathrm{N}$ during this period were measured. Cages $\mathrm{I}$ and 2 each contained two rats that had been malnourished on the low-protein diet, and cage 3 contained two rats that had been malnourished on restricted amounts of the high-protein diet. In addition, in cage 4 there was a normal control animal of the same age as the other rats, and being fed on the same diet.

Food intake was recorded daily, after weighing of the unconsumed food. Excreta were collected under toluene in I- or 2-day periods, in a jar placed below the funnel of each cage; hairs rubbed from the animals' skins also accumulated in the funnels and were scraped down into the jar at the end of each collection period. The contents of the jars were divided for convenience into a supernatant liquid part, mainly urine, and a residual semi-solid part, mainly faeces, and these portions were each mixed, sampled and analysed; but no attempt was made to measure exactly the separate urinary, faecal and cutaneous excretions of $\mathrm{N}$. It had been found that after thorough scraping of the unconsumed food from the food pots, and of excreta from the cages and funnels, washing the pots, cage and funnel in distilled water recovered in the water a further mean amount of $32 \mathrm{mg} \mathrm{N}$ per cage per period, and that this systematic error did not vary with the length of the period. Therefore in the final calculation $32 \mathrm{mg}$ was subtracted from the $\mathrm{N}$ balance for each cage in each period. 


\section{Killing and dissection of the animals}

The animals were killed and dissected as described by Cabak et al. (Ig63). The organs and the remainder of the carcass from all the animals in a group were pooled, and then each pooled sample was analysed separately. The animals whose $\mathrm{N}$ balance was measured were analysed separately.

\section{Chemical methods}

The treatment of the organs and carcasses and the determination of water, fat and total and collagen $\mathrm{N}$ were as described by Cabak et al. (1963). $\mathrm{N}$ was determined in the food and excreta by the method used for the tissues.

\section{Calculation of increments}

Three groups of six rats that had been subjected to each of the same three treatments as the animals to be rehabilitated (low-protein, high-protein low-calorie, and control diets) were killed, and the bodies and organs of each group were weighed and analysed for water, fat and $N$ (Cabak et al. $196_{3}$ ). The weights of the organs of the rehabilitated animals at the bcginning of rehabilitation were calculated from their body-weights at that time and the percentage contribution of the organs to the body-weights of the animals that were killed. These calculated weights of the organs and the weight of the body at the beginning of rehabilitation were then divided by 100 and multiplied by the percentage of $\mathrm{N}$, either total $\mathrm{N}$, non-collagen $\mathrm{N}$ or collagen $\mathrm{N}$ as the case might be, that had been found in the animals that were killed. The $\mathrm{N}$ deposited in the bodies and organs of the animals was calculated from the difference in $\mathrm{N}$ content at the beginning and end of the period of rehabilitation. In the animals used in the balance experiment, the calculated amount of $\mathrm{N}$ stored in the body was compared with the $\mathrm{N}$ storage as calculated from the $\mathrm{N}$ balance figures.

\section{RESULTS}

\section{Body-weights}

Fig. I shows the changes in the mean body-weights of each group of animais during the 27 days of rehabilitation. All the animals gained weight on both diets. Those that had previously been undernourished gained more than those that had not; in fact their rate of gain was similar to that of the control animals during the first 4 weeks of the whole investigation (Cabak et al. I963). Their weights had not, however, reached those of the control animals by the time the experiment came to an end. The rats that received the high-protein diet gained a little more weight than the animals in the corresponding groups that received the high-protein and starch diet. Table I shows that the difference in body-weight gain was still evident when the gains were expressed on an empty fat-free body basis, and that it was partly accounted for by the difference in weight of the liver, which grew more when the animals were given the high-protein diet alone than when they were given this diet mixed with starch. 


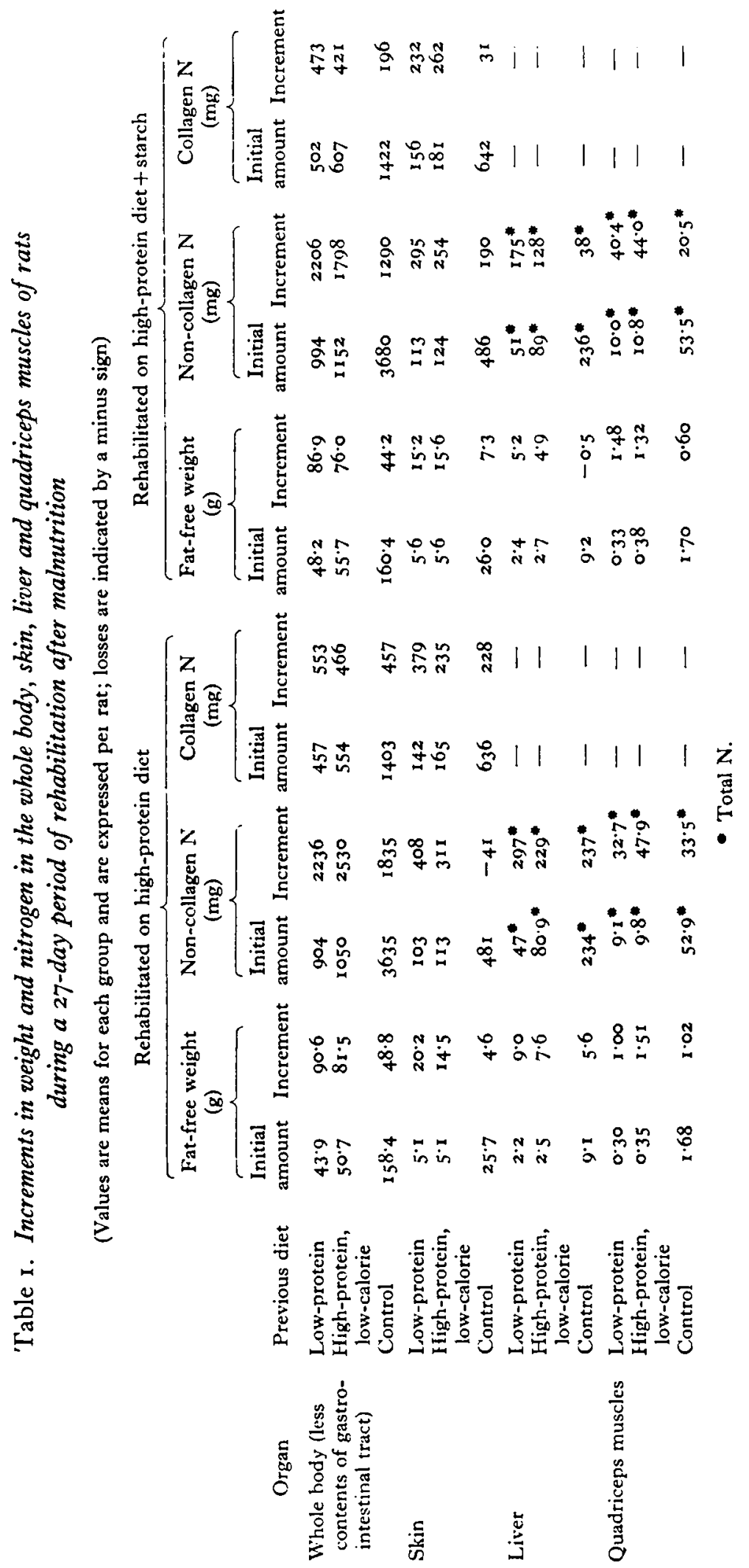




\section{Body composition}

Table I shows that the rats previously fed on the high-protein diet in limited amounts and the control animals, but not the animals previously fed on the low-protein diet in unlimited amounts, retained more $\mathrm{N}$ when given the high-protein diet than those that were given this diet mixed with starch. In all six groups of animals, collagen $\mathrm{N}$ accounted for $13-20 \%$ of the total $\mathrm{N}$ deposited.

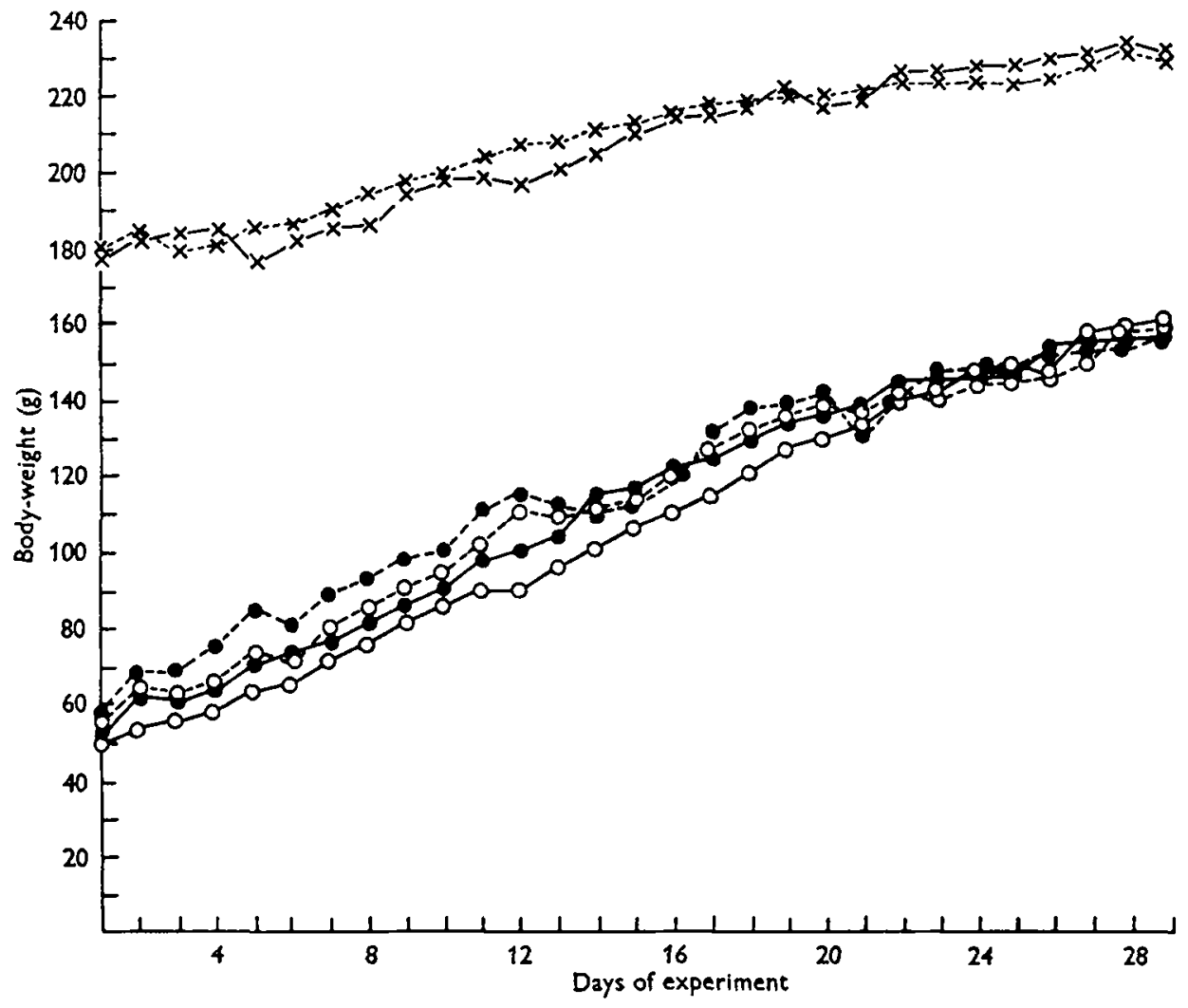

Fig. I. Changes in mean body-weights of rats. $O-O$, malnourished on the low-protein diet, rehabilitated on the high-protein diet; $0--0$, malnourished on the low-protein diet, rehabilitated on the high-protein diet mixed with starch; - -0 , malnourished on restricted amounts of the high-protein diet, rehabilitated on the high-protein diet; --- malnourished on restricted amounts of the high-protein diet, rehabilitated on the high-protein diet mixed with starch; $x-\times$, control animals given the high-protein diet; $x-\cdots x$, control animals given the high-protein diet mixed with starch.

The effect of the diet used for rehabilitation on the growth of the liver has been mentioned above. In the low-protein animals given the high-protein diet the growth of the liver accounted for $10.6 \%$ of the total $\mathrm{N}$ deposited in the body. The concentration of urea in the plasma was raised in all animals having the high-protein diet. In the animals previously malnourished on the low-protein diet the value was $104 \mathrm{mg} / \mathrm{100} \mathrm{ml}$ as compared with $43 \mathrm{mg} / \mathrm{r} 00 \mathrm{ml}$ on the high-protein diet and starch; in those previously 
malnourished on the high-protein, low-calorie diet, the values were 94 and $40 \mathrm{mg}$ respectively and in the control animals the values were 86 and $35 \mathrm{mg}$ respectively.

The change in total muscle mass during the period of rehabilitation was not determined. It will be seen, however, that the quadriceps muscles grew more in the animals previously fed on the control diet, and possibly also in those previously fed on the high-protein, low-calorie diet when they were fed on the high-protein diet alone than when this diet was mixed with starch. In the animals malnourished on the lowprotein diet the reverse was true. In the control animals given the high-protein diet, the growth of the quadriceps muscles was greater relative to the increase in bodyweight than in any of the other groups.

In contrast to the quadriceps muscles, the skin gained more weight when the animals that had been malnourished on the low-protein diet were rehabilitated on the high-protein diet alone than when they were rehabilitated on this diet mixed with starch; more of both nitrogenous fractions were deposited in the skin on the former

Table 2. Comparison of nitrogen retention as measured in balance tests with rats during a 27-day period of rehabilitation after malnutrition with the accumulated $N$ found by carcass analysis

\begin{tabular}{|c|c|c|c|c|c|}
\hline \multicolumn{3}{|l|}{2} & \multicolumn{3}{|c|}{$\mathrm{N}$ retention $(\mathrm{g})$} \\
\hline Cage no." & $\begin{array}{c}\text { Initial N content } \\
\text { of bodies } \\
(\mathrm{g})\end{array}$ & $\begin{array}{c}\text { Final } N \text { content } \\
\text { of bodies } \\
(\mathrm{g})\end{array}$ & $\begin{array}{l}\text { Measured by } \\
\text { carcass analysis } \\
\text { (a) }\end{array}$ & $\begin{array}{l}\text { Measured by } \\
\text { balance test } \\
(b)\end{array}$ & $\begin{array}{l}\text { Discrepancy } \\
\qquad(b-a)\end{array}$ \\
\hline $\mathbf{I}$ & 3.00 & $6 \cdot 5^{6}$ & $3 \cdot 56$ & $4 \cdot 36$ & 0.80 \\
\hline 2 & $3 \cdot 8 \mathrm{I}$ & $8 \cdot 54$ & 4.73 & $6 \cdot 57$ & $1 \cdot 84$ \\
\hline 3 & $3 \cdot 5^{8}$ & $7 \cdot 07$ & 3.49 & $5^{.03}$ & 1.54 \\
\hline 4 & 4.49 & $6 \cdot 20$ & $1 \cdot 71$ & 2.99 & $x \cdot 28$ \\
\hline
\end{tabular}

- See p. 618. While in the metabolic cages, all animals were given a mixture of the high-protein diet and starch.

diet, and the skin accommodated $28 \%$ of the total $\mathrm{N}$ deposited in the body. The protein content of the diet used for rehabilitation did not affect the growth of the skin, or the deposition of $\mathrm{N}$ in it, in the animals previously malnourished on restricted amounts of the high-protein diet. In both the groups that had previously had the high-protein, low-calorie diet the $\mathrm{N}$ deposited in the skin accounted for about $20 \%$ of the total $\mathrm{N}$ deposited in the body. The skin accounted for somewhat less of the increase in bodyweight and of total body $\mathrm{N}$ in the control animals than in either of the previously malnourished groups, but even here the $N$ deposited in the skin accounted for $8 \cdot 2$ and $14.9 \%$ of the total deposited in the body in those animals having the high-protein and the high-protein + starch diet respectively.

\section{Balance experiment}

Table 2 shows the $\mathrm{N}$ retention of rats rehabilitated on the high-protein diet mixed with starch, first as measured by the difference between intake and cxcretion, and second as measured by analysis of the rats' carcasses. The difference in the $\mathrm{N}$ content of the animals' carcasses at the beginning and the end of the 27 -day rehabilitation period was in every instance smaller than the recorded $\mathrm{N}$ 'retention'. There was no consistent dif- 
ference between the results for the different cages: the magnitude of the discrepancy showed no ascertainable relationship with the animals' growth rate or previous dietary history.

A calculation often made for practical purposes in studies of $\mathrm{N}$ balance is the alteration of weight of the lean tissue (i.e. body minus fat). This calculation involves an assumption about the percentage of $\mathrm{N}$ in lean tissue, and this assumption was checked by experiment during our observations on rats. The results given in Table 3 indicate that the lean tissue added to the animals' bodies during the period of rehabilitation contained about $3 \% \mathrm{~N}$. This result is somewhat lower than those summarized by Pace $\&$ Rathbun (1945) for six species of adult mammal whose mean $\mathrm{N}$ concentration was $3.52 \%$ of the lean tissue.

Table 3. Relation of protein retention measured by carcass analysis to increase in fat-free tissue of rats during a 27-day period of rehabilitation after malnutrition

\begin{tabular}{|c|c|c|c|c|c|}
\hline Cage no.* & $\begin{array}{c}\text { Increase in } \\
\text { body-weight } \\
\text { (g) }\end{array}$ & $\begin{array}{l}\text { Increase in fat } \\
\text { (g) }\end{array}$ & $\begin{array}{c}\text { Increase in } \\
\text { fat-free } \\
\text { body tissue } \\
\text { (g) }\end{array}$ & $\begin{array}{l}\mathrm{N} \text { retention } \\
\text { (g) }\end{array}$ & $\begin{array}{c}\text { Percentage of } N \\
\text { in fat-free body } \\
\text { tissue }\end{array}$ \\
\hline I & 134 & $17 \cdot 6$ & $116 \cdot 4$ & $3 \cdot 56$ & $3 \cdot 06$ \\
\hline 2 & 177 & $23 \cdot 0$ & $\times 54^{\circ} 0$ & 473 & 3.07 \\
\hline 3 & 139 & 18.5 & 120.5 & 3.49 & $2 \cdot 90$ \\
\hline 4 & 53 & 0.7 & $52: 3$ & $1 \cdot 71$ & 3.25 \\
\hline
\end{tabular}

- See p. 6r8. While in the metabolic cages, all animals were given a mixture of the high-protein diet and starch.

\section{DISCUSSION}

\section{Body composition}

In Widdowson \& McCance's (1957) experiment on the rehabilitation of proteindeficient rats, and in that of Wallace, Weil \& Taylor (1958) on growing rats, the animals having higher intakes of $\mathrm{N}$ gained more weight. Wallace $e t$ al. did not find any difference in the percentage of $\mathrm{N}$ in the bodies of their rats fed on the high- and lowprotein diets. In our rats the greater rise in fat-free body-weight of the rats rehabilitated on the high-protein diet was partly accounted for by the larger livers of these animals, and a difference in body composition was apparent only in those animals that had previously had the high-protein, low-calorie diet and in the control animals. It therefore seems possible that the ability of the animals malnourished on the lowprotein diet to incorporate the additional $\mathrm{N}$ was to some degree impaired. This result suggests that some of the enzyme systems of the body may not have recovered completely from the damage caused by the protein deficiency. If it is so, however, rats must differ from human infants for, although the enzymes of the pancreatic juice, for instance, are greatly reduced in children with protein malnutrition (Thompson \& Trowell, 1952; Gómez, Ramos Galván, Cravioto \& Frenk, 1954), they quickly return to normal levels on treatment. Similarly, the activity of enzyme systems involved in the removal of the end-products of protein metabolism, for example xanthine oxidase in the liver, is greatly reduced in protein deficiency both in rats (Miller, 1948; Allison \& Fitzpatrick, 1960) and in human infants (Burch, Arroyave, 
Schwartz, Padilla, Béhar, Viteri \& Scrimshaw, 1957). In human infants there is a rise in the level of the enzyme after treatment (Waterlow, 1962) but this may not take place so rapidly in the rat.

The greater growth of the liver in response to a high-protein diet has been observed before (Lightbody \& Kleinman, 1939; Widdowson \& McCance, 1957), and cannot be considered necessarily to be one of the beneficial effects of a high-protein diet. It may be merely an adaptation to meet the necessity of dealing with the large amounts of amino acids absorbed. This greater protein turnover is reflected in the high levels of urea in the blood (Snyderman, Boyer, Kogut \& Holt, 1958; Fomon, 196r).

Undernutrition (Dickerson \& McCance, 1960; Widdowson, Dickerson \& McCance, 1960) and protein deficiency (Widdowson \& McCance, 1957; Cabak et al. 1963) produce an increase in the amount of extracellular fluid (chloride 'space') per unit weight of muscle. In malnourished animals it could result from the thinning, or loss, of muscle fibres. There was no evidence that the muscle cells of the malnourished rats used in this experiment were more 'dilute' than normal, and it is concluded that the $\mathrm{N}$ deposited in the muscles during rehabilitation was used to expand the existing muscle cells, or to form new ones, with a resulting fall in the volume of extracellular fluid, but without change in the composition of the cells. The quadriceps muscles of the lowprotein animals, like the rest of the body (excluding the liver), did not grow any faster or deposit any more $\mathrm{N}$ with the diet containing the higher percentage of protein.

During rehabilitation the deposition of collagen accounted for about $20 \%$ of the total $\mathrm{N}$ deposited in the body. Since this protein contains $\mathrm{I} 8 \% \mathrm{~N}$ as compared with the usually assumed $16 \%$, and moreover is present in those organs, the skin and bones, that contain less water than the usually assumed value of $67 \%$, it is clear that gain in weight of tissue calculated from retention of $\mathrm{N}$ without regard to the form in which the $\mathrm{N}$ may be deposited will be considerably overestimated. This error may help to explain the results obtained by Holmes et al. (1954) during the rehabilitation of malnourished African adults.

The importance of the contribution of the skin to the $\mathrm{N}$ lost from the body during malnutrition has been demonstrated (Dickerson \& Cabak, I962; Cabak et al. 1963), and about one-third of the $\mathrm{N}$ retained in the body during rehabilitation was deposited in this organ. It seems reasonable to suppose that the skin is also the site of deposition of much of the $\mathrm{N}$ retained during the rehabilitation of human beings with protein deficiency.

\section{Balance experiment}

A considerable portion of the retained $\mathrm{N}$ as measured by the balance technique was not recovered in the bodies of the rats by analysis. The systematic error in the balances was reduced by including the washings of the containers in which food was offered and excreta were collected, but even when this was done, some $\mathrm{N}$ was missing; indeed, even if the allowance for this 'washings' error had been doubled, the discrepancy would not have been appreciably lessened. The absolute magnitude of the discrepancy between the results for 'balance' $\mathrm{N}$ and 'carcass' $\mathrm{N}$ was independent of the rate at which the animal was growing, of its dietary history and of the amount of its food intake. It follows therefore that, if expressed as a percentage of the $\mathrm{N}$ retention 
or intake, the 'missing' $\mathrm{N}$ would be considerably greater in the more slowly growing animals. This is in accordance with the findings of Nehring, Laube, Schwerdtfeger, Schiemann, Haesler \& Hoffmann (1957) that in growing rats and pigs the percentage $\mathrm{N}$ 'loss' becomes greater as the animal grows older.

Whether the discrepancy is due to an overestimate of the $\mathrm{N}$ retention by the balance technique, or an underestimate of $\mathrm{N}$ in the carcass, or both, remains to be discovered. The suggestion by Costa (1960), that the exchange of gaseous $\mathrm{N}$ in the lungs participates in the $\mathrm{N}$ balance of the body when excess dietary $\mathrm{N}$ is offered, deserves investigation. Sanslone \& Squibb (1962), when making observations similar to ours on young growing chickens, digested the entire carcass in hot hydrochloric acid immediately after death. This procedure for carcass analysis would clearly entail smaller losses of $\mathrm{N}$ than the method used in this work, in which the rats were dissected and certain organs and tissues analysed separately; and indeed, Sanslone \& Squibb were able to recover from the chickens' carcasses after 4 - or 8-day balance periods as much as $96 \%$ of the $\mathrm{N}$ recorded as $\mathrm{N}$ retention during the balance study.

The expected discrepancy between measured and calculated gain in body-weight has also occurred in our experiment. If the figures for $\mathrm{N}$ retention by balance (column 4, Table 2) are multiplied by 33 to give calculated lean tissue gain, the resultant figures are in every instance larger than the increases in body-weight. But, once again, the discrepancy is not greater in the animals (cages I-3) that were being rehabilitated after protein deficiency or calorie deficiency than in the animal (cage 4) that was growing normally.

These observations show that one cannot accurately predict the composition of rats' bodies by means of $\mathrm{N}$-balance studies, and if it is so in rats, in which balance tests can be performed over several weeks on constant and homogeneous diets, it is even less probable that such predictions can be made in man. In man, the usefulness of $\mathrm{N}$ balance studies may be confined to the qualitative detection of a large positive or negative balance or of a change from one to the other.

\section{SUMMARY}

I. Young rats that had been fed on a diet deficient in protein, or in calories, were rehabilitated for 27 days on a high-protein diet, or on a $1: 2$ mixture of this diet with soluble starch. Control animals of the same age as the malnourished ones were also fed on one or other of these two diets. The animals were then killed and their bodies and organs weighed and analysed.

2. Some of each kind of malnourished animals and a control animal were placed in metabolism cages for the 27 -day period. They were fed on the protein and starch diet, and their nitrogen balances were measured.

3. The consistently greater increase in fat-free body-weight of the animals that received the high-protein diet was wholly accounted for by the difference in weight of the liver, which grew more when this diet was given alone than when it was given mixed with starch. The animals previously malnourished on the diet deficient in calories and the control animals, but not those malnourished on a diet deficient in protein, deposited more $\mathrm{N}$ in their bodies on the high-protein diet than they did on the 
one containing less protein. In all animals collagen $\mathrm{N}$ accounted for $13-20 \%$ of the total $\mathrm{N}$ deposited.

4. In all the malnourished animals the growth of the skin accounted for $20 \%$ or more of the total $\mathrm{N}$ retained.

5. The concentration of urea in the plasma was $86-104 \mathrm{mg} / 100 \mathrm{ml}$ in the animals receiving the high-protein diet as compared with $35-43 \mathrm{mg} / 100 \mathrm{ml}$ in those receiving the high-protein + starch diet.

6. In the balance experiment the rats' total $N$ retention, as measured by the difference between intake and excretion, was found to be greater than the $\mathrm{N}$ accumulated in the animals' carcasses during this period. The discrepancy for the 27 -day period varied between 0.8 and $\mathrm{I} .84 \mathrm{~g}$ in the different cages, and showed no relationship to the animals' growth rate or dietary history.

7. The relation between increase in lean tissue weight and retention of $\mathrm{N}$ found from analysis of the carcasses indicated that the lean tissue formed during rehabilitation contained about $3 \% \mathrm{~N}$.

The authors are grateful to Dr Elsie M. Widdowson for her help and encouragement in this investigation, and to Professor R. A. McCance for his interest and helpful criticism of the paper. The technical assistance of Mr P. John and Miss P. Boudier has been much appreciated.

\section{REFERENCES}

Allison, J. B. \& Fitzpatrick, W. H. (1960), Dietary Proteins in Health and Disease. Springfield: C. C. Thomas.

Benjamin, E. (1914). Z. Kinderheilk. ro, 185.

Bray, B. (1953). Brit. Y. Nutr. 7, 3 .

Burch, H. B., Arroyave, G., Schwartz, R., Padilla, A. M., Béhar, M., Viteri, F. \& Scrimshaw, N. S. (1957). F. clin. Invest. 36, 1579 .

Cabak, V., Dickerson, J. W. T. \& Widdowson, E. M. (1963). Brit. J. Nutr. 17, 601.

Costa, G. (1960). Nature, Lond., 188, 549.

Dickerson, J. W. T. \& Cabak, V. (1962). Proc. Nutr. Soc. 21, iii.

Dickerson, J. W. T. \& McCancc, R. A. (1960). Brit. 7. Nutr. 14, 33 1.

Fomon, S. J. (1961). Pediatrics, Springfield, 28, 347.

Gómez, F., Ramos Galván, R., Cravioto, J. \& Frenk, S. (1954). Pediatrics, Springfield, r3, 548.

Holmes, E. G., Jones, E. R. \& Stanier, M. W. (1954). Brit. Y. Nutr. 8, 173.

Lightbody, H. D. \& Kleinman, A. (1939). J. biol. Chem. 129, 71.

Miller, L. I. ( 1948). F. biol. Chem. 172, 113 .

Nehring, K., Laube, W., Schwerdtfeger, E., Schiemann, R., Haesler, E. \& Hoffmann, L. (1957). Biochem. Z. 328, 549.

Pace, N. \& Rathbun, E. N. (1945). F. biol. Chem. 158, 685.

Passmore, R., Meiklejohn, A. P., Dewar, A. D. \& Thow, R. K. (I955). Brit. J. Nutr. 9, 27.

Sanslone, W. R. \& Squibb, R. L. (1962). Brit. 7. Nutr. r6, 59.

Snyderman, S. E., Boyer, A., Kogut, M. \& Holt, L. E. Jr. (1958). Amer. F. Dis. Child. 96, 63 I.

Thompson, M. D. \& Trowell, H. C. (1952). I ancet, i, I03 I.

Wallace, W. M. (1959). Fed. Proc. 18, 1125.

Wallace, W. M., Weil, W. B. \& Taylor, A. (1958). Ciba Foundation Colloquia on Ageing, 4, I16.

Waterlow, J. C. (1961). F. trop. Pediat. 7, 16.

Waterlow, J. C. (1962). In Protein Metabolism, p. 9o. [F. Gross, editor.] Berlin: Springer Verlag.

Waterlow, J. C., Cravioto, J. \& Stephen, J. M. I.. (1960). Advanc. Protein Chem. 15, I3I.

Waterlow, J. C. \& Wills, V. G. (1960). Brit. F. Nutr. 14, 183.

Widdowson, E. M., Dickerson, J. W. T. \& McCance, R. A. (1960). Brit. F. Nutr. 14, 457.

Widdowson, E. M. \& McCance, R. A. (1954). Spec. Rep. Ser. med. Res. Coun., Lond., no. 287.

Widdowson, F. M. \& McCance, R. A. (1957). Brit. Y. Nutr. I1, 198. 